\title{
Management Strategies for Bank’s Liquidity Risk
}

\author{
Sviatlana Hlebik ${ }^{1} \&$ Lara Ghillani $^{2}$ \\ ${ }^{1}$ Ph.D. Università Cattolica del Sacro Cuore, Milan; Università di Parma; Crédit Agricole Cariparma, Italy \\ ${ }^{2}$ Crédit Agricole Cariparma, Italy \\ Correspondence: Sviatlana Hlebik, Ph.D. Università Cattolica del Sacro Cuore, Milan; Università di Parma; \\ Crédit Agricole Cariparma, Italy. E-mail: hlebiks@gmail.com
}

Received: March 6, 2017

Accepted: May 3, 2017

Online Published: May 15, 2017

doi:10.5539/ijef.v9n6p98

URL: https://doi.org/10.5539/ijef.v9n6p98

The views expressed in this paper are those of the authors and not necessarily of the organization with which they are affiliated.

\begin{abstract}
Liquidity risk management is today a major focus for regulators, due to increasing complexity of financial markets and concerns related to inadequate identification and managing liquidity risk, exacerbated by the financial crisis. Because the financial market is increasingly interconnected, a liquidity shortfall at a single institution can have system-wide consequences.

This paper aims to provide analytical explanations of how important decisions made by bank managers can influence the capability of an institution to finance increases in assets and meet their commitments without impairing cash flow. Banks are particularly susceptible to liquidity risk because the maturity transformation from short-term deposits into long-term loans is one of their key business activity. Further, there can be uncertainties in cash-flow in the external occurrences and agents' behavior. Skillful liquidity risk management is essential, and the present work analyses impact of some management strategies on Basel III liquidity ratios.
\end{abstract}

Keywords: banks, Basel III, liquidity risk, banking regulation

\section{Introduction}

The recent crisis has made it clear that liquidity plays a key role in the operation of financial markets. Banks ran into trouble when they failed to handle liquidity correctly. They relied excessively on short-term funding, depended on other financial institutions for funding, and jeopardized their proper functioning by possessing inadequate levels of liquid assets in funding crises. The financial crisis of 2007-2008 is a good example of how quickly liquidity can disappear and how long the illiquidity period can last. It shows that it is crucial for institutions to be able to manage liquidity risk effectively. Furthermore, it shows that in the business community, all contributors are closely interconnected and any occurrence can impact on the economic system as a whole. Liquidity risk management is of enormous importance in this scenario.

According to the Fundamental Principles for the management and supervision of liquidity risk (BCBS, 2008) liquidity is the "ability of a bank to fund increases in assets and meet obligations as they come due, without incurring unacceptable losses". Liquidity risk management is extremely important not only for a single institution, but also for the whole system, since the consequences of liquidity shortage can be acutely felt on both levels as a chain reaction from a single institution to the system as a whole. Banks are therefore responsible for sound management of liquidity risk aiming at preserving an adequate level of liquidity, cushioning unencumbered high quality liquid assets, as well as being prepared to meet a range of stress events, possible losses or impairments of funding sources. During the last 10 years the complexity and management of liquidity risk has been further increased by financial market developments. The Basel III framework "aims to improve the banking sector's ability to absorb shocks arising from financial and economic stress, thus reducing the risk of spillover from the financial sector to the real economy" (BCBS, 2011).

It is therefore clear that any senior executive team involved in the development of business strategies for managing liquidity risk must have a sufficient level of competence and appropriate knowledge. The Board of Directors should be regularly provided with analytic data on the bank's liquidity developments in order to ensure 
an adequate response to changing business conditions, and to improve the risk tolerance of the bank. On the basis of updated information, the Board of Directors approves a strategy and liquidity management policy. The main factors in performance evaluation are the bank's business and product mix, balance sheet structure and cash flow profiles for all types of obligations. Bank liquidity requirements, and the necessary sources of liquidity vary. The bank should therefore evaluate each item on this list, as well as all possible potential losses, in order to be well-prepared for any negative effect on liquidity.

The remainder of this chapter is organized as follows. Section 1 introduces the concepts and the study's main arguments. Section 2 provides a brief literature review on the subject. Section 3 discusses challenges to liquidity risk management in banking. Section 4 discusses the research methodology and introduces a number of actions (maneuvers) that can be performed to improve a bank's liquidity risk management capabilities. Section 5 presents the research findings and results. Applying the simulation-based approach to decision making, the results of sensitivity analysis determine the impact of actions on liquidity measurement ratios. Conclusions follow in Section 5. Appendix 1 explains the construction of the stylized bank sheet and its calibration through optimization problems. The Required stable funding (RSF) and Available stable funding (ASF) factors and categories are outlined in Appendix 2.

\section{Literature Review}

The International Regulatory Framework For Banks (Basel III) introduces new LCR and NSFR standards. These two new liquidity ratios - the short-term Liquidity Coverage Ratio (LCR) and the longer-term Net Stable Funding Ratio (NSFR) - respond to the need for banks to increase their high-quality liquid assets and obtain more stable sources of funding, while requiring that they adhere to sound principles of liquidity risk management.

One of the two standards introduced by Basel III is a 30-day Liquidity Coverage Ratio (LCR) which is intended to promote short-term resilience to potential liquidity disruptions. The LCR has been designed to require global banks to have sufficient high-quality liquid assets to withstand a stressed 30- day funding scenario specified by supervisors. The LCR numerator consists of a stock of unencumbered, high-quality liquid assets that must be available to cover any net outflow, while the denominator is comprised of cash outflows less cash inflows (subject to a cap at $75 \%$ of outflows) that are expected to occur in a severe stress scenario. The LCR was revised by the Committee in January 2013 and came into effect on 1 January 2015. The LCR has been mandatory, on a consolidated basis, from October 2015 (i.e.: at 60\%) and the phase-in period will finish by January 2018 (BCBS, 2013; BCBS, 2014a).

European Banking Authority crucial contributes in evaluation the liquidity risk profile and the performance of the institutions in the EU banking sector in relation to the LCR regulation (EBA, 2013; EBA, 2014a). The EBA has a mandate related to liquidity risk from the Capital Requirements Regulation (CRR).

The second standard introduced by Basel III is the Net Stable Funding Ratio (NSFR), a longer-term structural ratio to address liquidity mismatches and provide incentives for banks to use stable sources to fund their activities. NSFR is calculated as the ratio between the amount of available funding (liabilities and equity) and required funding (to fund the assets) over a one-year horizon (i.e. balance sheet perspective). The NSFR is also required to be equal to or above $100 \%$. Stable funding for the purposes of NSFR calculation is defined as those types of equity and liabilities expected to be reliable sources of the funds under an extended stress scenario of one year.

The EBA report on Net Stable Funding Requirements under Article 510 of the CRR (EBA, 2015) analyzes the impact of introducing a stable funding requirement on the business and risk profiles of institutions and calibration of the Net Stable funding Ratio.

Ryan N. Banerjee and Hitoshi Mi (BIS, 2014) examine the impact of liquidity regulation on banks, in particular investigates how banks responded to tighter liquidity regulation in the United Kingdom. The results suggest that when the new more stringent liquidity regulation was introduced in the United Kingdom, it was a constraint on the composition of banks' assets and liabilities. The calibration of the high quality liquid assets to total assets was compensate by reduction in the share of short-term financial loans, meanwhile increased funding from more stable non-bank and non-financial corporation deposits and decreased their reliance on less stable short-term wholesale and non-UK funding.

The NSFR is currently subject to an observation and review by BCBS (Basel Committee on Banking Supervision), but it remains the Committee's intention that the NSFR will become a minimum standard by 1 January 2018. (BCBS, 2010; BCBS, 2014b). 


\section{Challenges to Liquidity Risk Management}

The financial crisis and previous requirements specified by Basel II led to comprehensive initiatives to improve capital and liquidity management becoming a frequent response by banks in the current market.

For an adequate and reasonable response to the challenges posed by Basel III, banks are required to firstly, improve capital efficiency and then correct suboptimal practical approaches to liquidity-management. In general, the measures and their potential effects vary between different banks, as their initial asset composition differs too.

The changes introduced by Basel III give banks the opportunity to change the structure of their business portfolios. A bank which has undertaken a number of necessary measures may later benefit from these changes as an important strategic advantage. Analysis needs to be carried out at all levels of bank management, and only when it has been completed should the structure of the business portfolio be finalised. It may be that the portfolio includes businesses with models with problematic fallout. Analysis should include an examination of the impact on each segment and product made by new capital, liquidity, funding and leverage requirements.

It is important to highlight that banks should redesign products in order to meet client needs and at the same time optimize capital and liquidity. For example, transaction accounts can also comprise investment capabilities. But under the new Basel III dispositions, transaction accounts receive beneficial treatment in terms of NSFR.

Banks may offer retail mortgages with interest paid on the net amount of outstanding credit and deposit. Here the bank is placing on the market a new integrated product that combines both financing and deposits. In addition, to attract stable funding, the bank can make other special offers such as deposits for retail businesses, as well as for other small and midsize businesses. In order to reduce funding costs, the bank should increase the share of short-maturity lending. This could be achieved by reducing the proportion of corporate mortgages, replacing them with revolving loans.

\section{Impact of Managers' Decisions on Liquidity Measurement-Sensitivity Analysis}

\subsection{The Levers to Streamline the Ratio of Liquidity LCR}

The goal of the banking groups is not only to comply with the minimum regulatory requirement during the phase-in. They also want to set a target level above the minimum requirement to ensure a cost/opportunity balance which gives a good ranking among leading competitors in addition to improving the efficiency of liquidity management. This balance, to be established in the Budget and Strategic Plan, needs to take into account the need for growth in terms of profitability of financial/banking activity as well as the need for high rankings in terms of liquidity between competitors.

So from this point of view, the liquidity ratio is a constraint to be managed. The following levers can be used to minimize the cost of efficient liquidity management.

The main lever for banks is the purchase of first level Assets - High quality liquid assets (HQLA) within their own country, and full allotment of liquidity by the ECB would be a good source of funding for this purpose.

In reality, this type of lever would not be completely effective for Italian banks at present, considering the yield of Italian government bonds and of the higher-rated countries. To compensate for low profitability, the banks find themselves in the position of having to differentiate between more useful Level 1 assets and Level 2 assets with yields that are currently low.

Other asset items that fall into the category of first-level assets, such as loans with Central Bank, are not sufficiently attractive, because the levels of yield are currently negative following the operations of ECB (TLTRO -Targeted Longer-Term Refinancing Operations and QE- Quantitative Easing). Money market rates, for this reason, will continue to be low over the medium period and therefore the Central Bank's loans cannot be a means to detain profitable cash reserves.

Considering that holding free reserves entails having liquid assets to invest for their purchase, it is necessary to act on the denominator of the LCR to raise stable and low-cost resources.

As for the levers applicable to the LCR denominator, we now analyze separately the items that generate inflows from those that generate outflows. Considering that the European Banking Authority (EBA) provides a cap on inflows equal to $75 \%$ of outflows, it is important to understand how these inflows can be obtained efficiently. Restrictions consist of cash flows over the 30 calendar-day period weighted according to the type of clientele. For example, retail customers have a weighted average of 50\%, while the Central Bank and Financial Institutions have a weighted average of $100 \%$. 
This might intuitively seem that interbank loans are preferable to loans to Financial Institutions. In fact, for reasons linked to market rates and the need to create interest margins, banks have to know how to drive the loan portfolio by finding the right balance between Retail and Corporate loans and loans from financial institutions and banks.

As the pilotage of the maturity of cash inflows from financial institutions and banks play a positive role in the management of the LCR, it is necessary to manage to advance short-term and long-term loans in order to maintain a good balance between interbank lending and customers to create a positive impact on the interest margin.

Although the inter-bank, in fact, gives higher rates only in the medium - long term part of the curve, loans to corporate customers generate good margins even in the short term. For example, overdrafts can be broken down according to regulatory segmentation, thanks to the introduction of a clause whereby the bank can demand the immediate return of the sum, and they can benefit from a hypothetically greater inflow.

In the management of outflows things becomes more complex. The cash flows both at sight and at term are treated according to certain rules concerning the type of customer (retail, corporate, IF, bank) the kind of relationship (operational, non-operational), the stability of the relationship itself and the type of underlying contractual agreement.

As for the type of customer, one of the levers that can be used to minimize the impact of outflows on the LCR is to prioritize the collection on stable Retail customers pursuing trade policies that favour the products and services, and who can be classified in category B3 "retail stable".

To avoid putting a strain on the Income statement, there could be a grid of economic conditions of current accounts for holders of accounts that are associated with certain products compliant with the legislation so that the better a customer meets the stability requirements the more profitable for him or her to maintain customer relationship with the bank.

Regarding the products in the Short Term bracket, intended for customers, the introduction of a clause into contracts preventing early repayment without a 32 day notice makes possible the negotiation of products that otherwise would be "treated in stock" and means that deadlines fall in different months of the year, creating a positive impact on the LCR ratio.

Solutions need to embrace more than interbank and retail deposits. Because of the current crisis, sources deriving from corporate customers need to be taken into account and can still contribute to diversify funding, even though they are more expensive and less stable. This diversification, if well managed through early redemption clauses, can help fix deadlines minimizing the impact on LCR.

In the medium term, considering current rates, using market sources such as emissions of covered bond can be a useful economic lever to ensure the necessary liquidity to increase eligible resources for LCR.

\section{Research Methodology}

\subsection{Sensitivity Analysis. Behavioral Adjustment Strategies Induced by LCR}

This section evaluates the impact of certain strategies on liquidity indicators. Bankscope data was used to build the model. Firstly, the stylized liquidity-based balance sheet format was based on 150 European Bank sheets. In order to make more detailed subdivisions of the items, which are not present in traditional balance sheets, qualitative analysis was made. It is important to highlight that under the article 460 of the Capital Requirements Regulation (EU 575/2013) and according to the Delegated Act LCR(EU 2015/61; EU 2015/62; EU 2015/63) has been mandatory, on a consolidated basis, from October 2015 (i.e.: at 60\%) and the minimum LCR requirement has to reach $100 \%$ by 1 January 2018 .

In this work, calculated values of Liquidity Coverage Ratio (LCR) were calibrated more precisely from bank's inflows and outflows using the BASEL III Monitoring Exercise(EBA 2014). The financial sector was studied using European Banking information. The European Banking Authority (EBA) has been monitoring and assessing the impact of the regulatory measures aimed at strengthening the supervision and risk management of the banking sector on a sample of EU banks. Appendix 1 contains methodological details on the model and construction and calibration of the LCR items. Net Stable Funding Ratio was made according to the structure of the NSFR disclosure standards from the BIS consultative document (See Appendix 2; BCBS, 2014b).

\section{Research Findings and Results}

Strategy 1: Sell non-liquid assets, buy liquid assets (impact on HQLA and inflows) 
It is assumed that non- HQLA reallocates with Level 1 HQLA.

As Level 1 HQLA attracts a lower weight of required funding (5\% RSF factor for Level 1 and between 65\% and $85 \%$ for other assets with a maturity of more than 12 months, for instance), the total RSF is lower, enabling the NSFR requirement to be met. It is assumed that the other assets swapped attract an $85 \%$ RSF factor. The output is shown in Figure 1.

Table 1. Strategy 1

\begin{tabular}{|c|c|c|c|c|c|c|c|c|c|c|c|}
\hline STRATEGY & $\begin{array}{c}\text { BALANCE } \\
\text { SHEET }\end{array}$ & ITEM LCR & ITEM NSFR & STRESS \% & $\begin{array}{c}\text { LCR } \\
\text { BEFORE } \\
\text { UNTER }\end{array}$ & $\begin{array}{c}\text { NSFR } \\
\text { BEFORE } \\
\text { UNTER }\end{array}$ & $\begin{array}{c}\text { LCR } \\
\text { AFTER }\end{array}$ & $\begin{array}{c}\text { NSFR } \\
\text { AFTER }\end{array}$ & $\Delta \mathrm{LCR}$ & $\triangle$ NSFR & $\begin{array}{c}\text { Impacts ON } \\
\text { liquidity } \\
\text { ratios }\end{array}$ \\
\hline $\begin{array}{l}\text { Sell non- } \\
\text { liquid } \\
\text { assets, buy } \\
\text { liquid } \\
\text { assets }\end{array}$ & $\begin{array}{c}\text { ASSETS } \\
\text { Qualifying } \\
\text { marketable } \\
\text { securities }\end{array}$ & $\begin{array}{l}\text { Reserve, } \\
\text { Inflows }\end{array}$ & $\begin{array}{l}\text { Required } \\
\text { funding } \\
\text { (RSF) }\end{array}$ & $10 \%$ & $107,30 \%$ & $102,00 \%$ & $112,20 \%$ & $103,31 \%$ & $4,90 \%$ & $1,31 \%$ & $\begin{array}{l}\text { Facilitate } \\
\text { complianœe } \\
\text { with the } \\
\text { LCR and } \\
\text { NSFR ratios }\end{array}$ \\
\hline
\end{tabular}

It is necessary to consider earnings and therefore capital implications if non-liquid assets are sold at a significant loss. On the capital side, because Level 1 HQLA attracts a lower risk weight than non-HQLA, the total amount of RWA decreases, lowering the capital ratio constraint. Leverage Ratio remains relatively constant, as the Leverage Ratio is not a risk-based measure, unless there is a significant loss on the asset disposal

It should be noted that, by applying the above described strategy, the opportunity cost for reducing earnings by selling more profitable products will be offset in terms of risk and liquidity reduction, benefiting in capital ratio (capital / RWA) terms.

\section{Strategy 2: Shortening maturities of assets}

Reducing maturity of assets increases the amount of cash flowing in within any 30-day period. A banking institution shall assign a 100\% inflow rate for loans to financial companies but only $50 \%$ for retail loans and non-financial wholesale loans. The result is shown in Figure-2.

Table 2. Strategy 2

\begin{tabular}{|c|c|c|c|c|c|c|c|c|c|c|c|}
\hline STRATEGY & $\begin{array}{l}\text { BALANCE } \\
\text { SHEET }\end{array}$ & ITEM LCR & $\begin{array}{l}\text { ITEM } \\
\text { NSFR }\end{array}$ & STRESS \% & $\begin{array}{c}\text { LCR } \\
\text { BEFORE } \\
\text { UNTER } \\
\end{array}$ & $\begin{array}{l}\text { NSFR } \\
\text { BEFORE } \\
\text { UNTER }\end{array}$ & $\begin{array}{c}\text { LCR } \\
\text { AFTER }\end{array}$ & NSFR AFTER & $\Delta \mathrm{LCR}$ & $\triangle$ NSFR & $\begin{array}{c}\text { Impacts ON } \\
\text { liquidity } \\
\text { ratios }\end{array}$ \\
\hline \multirow{2}{*}{$\begin{array}{l}\text { Shortening } \\
\text { maturities }\end{array}$} & $\begin{array}{c}\text { ASSETS } \\
\text { (performing } \\
\text { loans, Non- } \\
\text { financial } \\
\text { Corporate) } \\
\end{array}$ & Inflows & $\begin{array}{l}\text { Required } \\
\text { funding } \\
\text { (RSF) }\end{array}$ & $5 \%$ & $107,30 \%$ & $102,00 \%$ & $109,40 \%$ & $102,00 \%$ & $2,10 \%$ & $0,00 \%$ & $\begin{array}{c}\text { Facilitate } \\
\text { complianos } \\
\text { with the } \\
\text { LCR ratio }\end{array}$ \\
\hline & $\begin{array}{c}\text { ASSETS } \\
\text { (performing } \\
\text { loans, Credit } \\
\text { institutions) }\end{array}$ & Inflows & $\begin{array}{l}\text { Required } \\
\text { funding } \\
\text { (RSF) }\end{array}$ & $\begin{array}{c}5 \% \\
\text { from bucket }<1 \\
\text { Month to } \\
\text { bucket } \geq 1 \\
\text { month to }<6 \\
\text { months }\end{array}$ & $107,30 \%$ & $102,00 \%$ & $107,53 \%$ & $102,00 \%$ & $0,22 \%$ & $0,00 \%$ & $\begin{array}{c}\text { Facilitate } \\
\text { complianœe } \\
\text { with the } \\
\text { LCR ratio }\end{array}$ \\
\hline
\end{tabular}

\section{Strategy 3: Reducing committed lines (credit/liquidity)}

This maneuver impacts on cash outflows.

Table 3. Strategy 3

\begin{tabular}{|c|c|c|c|c|c|c|c|c|c|c|c|}
\hline STRATEGY & $\begin{array}{l}\text { BALANCE } \\
\text { SHEET }\end{array}$ & ITEM LCR & $\begin{array}{l}\text { ITEM } \\
\text { NSFR }\end{array}$ & STRESS \% & $\begin{array}{c}\text { LCR } \\
\text { BEFORE } \\
\text { UNTER }\end{array}$ & $\begin{array}{c}\text { NSFR } \\
\text { BEFORE } \\
\text { UNTER }\end{array}$ & $\begin{array}{c}\text { LCR } \\
\text { AFTER }\end{array}$ & NSFR AFTER & $\Delta \mathrm{LCR}$ & $\triangle \mathrm{NSFR}$ & $\begin{array}{c}\text { Impacts ON } \\
\text { liquidity } \\
\text { ratios }\end{array}$ \\
\hline $\begin{array}{l}\text { Reducing } \\
\text { committed lines } \\
\text { (credit/ } \\
\text { liquidity) }\end{array}$ & $\begin{array}{c}\text { OFF- } \\
\text { BALANCE } \\
\text { ASSETS } \\
\text { COMMITTED } \\
\text { CREDIT AND } \\
\text { LIQUIDITY } \\
\text { FACILITIES }\end{array}$ & Outflows & $\begin{array}{l}\text { Required } \\
\text { funding } \\
\text { (RSF) }\end{array}$ & $(-) 10 \%$ & $107,30 \%$ & $102,00 \%$ & $113,49 \%$ & $102,04 \%$ & $6,18 \%$ & $0,05 \%$ & $\begin{array}{l}\text { Facilitate } \\
\text { complianœe } \\
\text { with the } \\
\text { LCR and } \\
\text { NSFR ratios }\end{array}$ \\
\hline
\end{tabular}

Commitments are given on the basis of relatively high stressed outflow assumptions. The January 2013 Bank for International Settlements decision implies a reduction in the weights on outflows, as the unused portion of 
committed liquidity facilities to non-financial corporate, sovereigns, central banks and PSEs are now given a weight of $30 \%$ (previous weighting:100\%). Figure 3 shows the main results.

\section{Strategy 4: Lengthening short-term wholesale funding maturities}

This strategy impacts on cash outflows and adjusts the deposit funding structure - converting interbank deposits due within one month to one year to exhaust that effect. Converting interbank deposits to term could have a significant cost. There is a limit on banks' ability to convert short-term deposits, as some are operational and need to be at sight. The output is shown in Figure 4.

Table 4. Strategy 4

\begin{tabular}{|c|c|c|c|c|c|c|c|c|c|c|c|}
\hline STRATEGY & $\begin{array}{l}\text { BALANCE } \\
\text { SHEET }\end{array}$ & ITEM LCR & $\begin{array}{l}\text { ITEM } \\
\text { NSFR }\end{array}$ & STRESS \% & $\begin{array}{c}\text { LCR } \\
\text { BEFORE } \\
\text { UNTER }\end{array}$ & $\begin{array}{c}\text { NSFR } \\
\text { BEFORE } \\
\text { UNTER }\end{array}$ & $\begin{array}{c}\text { LCR } \\
\text { AFTER }\end{array}$ & NSFR AFTER & $\Delta \mathrm{LCR}$ & $\triangle$ NSFR & $\begin{array}{c}\text { Impacts ON } \\
\text { liquidity } \\
\text { ratios }\end{array}$ \\
\hline $\begin{array}{l}\text { Lengthening } \\
\text { short-term } \\
\text { wholesale } \\
\text { funding } \\
\text { maturities }\end{array}$ & $\begin{array}{l}\text { LIABILITIES } \\
\text { SHORT- } \\
\text { TERM } \\
\text { FUNDING } \\
\text { (interbank } \\
\text { deposits) }\end{array}$ & Outflows & $\begin{array}{l}\text { Available } \\
\text { funding } \\
\text { (ASF) }\end{array}$ & $\begin{array}{c}10 \% \\
\text { from bucket [<1 } \\
\text { Months] to } \\
\text { bucket }[\geq 6 \\
\text { months to }<1 \\
\text { year] }\end{array}$ & $107,30 \%$ & $102,00 \%$ & $112,76 \%$ & $102,00 \%$ & $5,46 \%$ & $0,00 \%$ & $\begin{array}{l}\text { Facilitate } \\
\text { complianœe } \\
\text { with the } \\
\text { LCR ratio }\end{array}$ \\
\hline
\end{tabular}

Strategy 5: Reducing short-term wholesale funding, increasing retail deposits (impact on cash outflows)

As retail deposits are given run-off rates of $3 \%, 5 \%$ or $10 \%$ respectively, under the current LCR definition, it is considered an inexpensive and stable way to get funding, as well as a preferential tool to improve the LCR. The result is shown in Figure 5.

Table 5. Strategy 5

\begin{tabular}{|c|c|c|c|c|c|c|c|c|c|c|c|}
\hline STRATEGY & BALANCE SHEET & ITEM LCR & $\begin{array}{l}\text { ITEM } \\
\text { NSFR }\end{array}$ & STRESS $\%$ & $\begin{array}{c}\text { LCR } \\
\text { BEFORE } \\
\text { UNTER }\end{array}$ & $\begin{array}{c}\text { NSFR } \\
\text { BEFORE } \\
\text { UNTER }\end{array}$ & $\begin{array}{c}\text { LCR } \\
\text { AFTER }\end{array}$ & NSFR AFTER & $\Delta \mathrm{LCR}$ & $\triangle$ NSFR & $\begin{array}{l}\text { Impacts ON } \\
\text { liquidity } \\
\text { ratios }\end{array}$ \\
\hline $\begin{array}{c}\text { Reducing } \\
\text { short-term } \\
\text { wholesale } \\
\text { funding, } \\
\text { increasing } \\
\text { retail } \\
\text { deposits }\end{array}$ & $\begin{array}{c}\text { LIABILITIES } \\
\text { TERM DEPOSITS- } \\
\text { (Small business } \\
\text { customers-Less } \\
\text { stable 10\%) } \\
\text { SHORT-TERM } \\
\text { FUNDING } \\
\text { (interbank } \\
\text { deposits } 100 \% \text { ) }\end{array}$ & Outflows & $\begin{array}{l}\text { Available } \\
\text { funding } \\
\text { (ASF) }\end{array}$ & $\begin{array}{c}10 \% \\
\text { from bucket } \\
\text { [<1 Months] to } \\
\text { bucket }[\geq 6 \\
\text { months to } \\
<1 \text { year] }\end{array}$ & $\begin{array}{c}107,30 \\
\%\end{array}$ & $102,00 \%$ & $112,19 \%$ & $102,00 \%$ & $4,89 \%$ & $0 \%$ & $\begin{array}{l}\text { Facilitate } \\
\text { compliance } \\
\text { with the } \\
\text { LCR ratio }\end{array}$ \\
\hline
\end{tabular}

The increase in retail deposits might be used as an adjustment tool to help banks reach the required level of LCR. Nevertheless, there are some exogenous effects that must be taken into account, including the likeliness of retail deposit competition. This competition could lead to an under-optimal equilibrium where banks increase the average rate paid to retail customers for their deposits, without succeeding in attracting more deposits (neutralization effect).

Strategy 6: 'Leveraging': Buying liquid assets, funded by issuing long-term wholesale debt

It's implies an increase in long-term funding and the simultaneous increase in eligible asset holdings.

In this strategy, it is assumed that if banks cannot reach the level of $100 \%$ by lengthening the maturities on the liability side, they "would raise additional unsecured with two year maturity to increase the liquid asset buffer assuming the cash proceeds from the 2-year unsecured debt are reinvested in 2-year government bonds which would qualify as level-1 assets'. The result is shown in Figure-6

Table 6. Strategy 6

\begin{tabular}{|c|c|c|c|c|c|c|c|c|c|c|c|}
\hline STRATEGY & $\begin{array}{l}\text { BALANCE } \\
\text { SHEET }\end{array}$ & ITEM LCR & $\begin{array}{l}\text { ITEM } \\
\text { NSFR }\end{array}$ & STRESS $\%$ & $\begin{array}{c}\text { LCR } \\
\text { BEFORE } \\
\text { UNTER }\end{array}$ & $\begin{array}{c}\text { NSFR } \\
\text { BEFORE } \\
\text { UNTER }\end{array}$ & $\begin{array}{c}\text { LCR } \\
\text { AFTER }\end{array}$ & NSFR AFTER & $\Delta \mathrm{LCR}$ & $\triangle$ NSFR & $\begin{array}{c}\text { Impacts ON } \\
\text { liquidity } \\
\text { ratios }\end{array}$ \\
\hline $\begin{array}{l}\text { Buying liquid } \\
\text { assets, funded } \\
\text { by issuing long- } \\
\text { term wholesale } \\
\text { debt } \\
\text { (Leveraging) }\end{array}$ & $\begin{array}{c}\text { ASSETS } \\
\text { Qualifying } \\
\text { marketable } \\
\text { securities, } \\
\text { LONG TERM } \\
\text { FUNDING }\end{array}$ & $\begin{array}{l}\text { Reserve, } \\
\text { Outflows }\end{array}$ & $\begin{array}{l}\text { Required } \\
\text { funding } \\
\text { (RSF) }\end{array}$ & $\begin{array}{c}10 \% \text { of } \\
\text { Qualifying } \\
\text { marketable } \\
\text { securities, bucket } \\
\text { [ } \geq 6 \text { months to }< \\
1 \text { year] }\end{array}$ & $107,30 \%$ & $102,00 \%$ & $112,19 \%$ & $102,40 \%$ & $4,89 \%$ & $0,40 \%$ & $\begin{array}{l}\text { Facilitate } \\
\text { complianœ } \\
\text { with the } \\
\text { LCR and } \\
\text { NSFR ratios }\end{array}$ \\
\hline
\end{tabular}




\section{Conclusion}

This paper presents some of the challenges to liquidity risk management and evaluates the impact of managers' decisions on liquidity ratios. Banks can adjust liquidity ratios in various ways, depending on their business features.

If banks decide to increase the liquid portion of assets, risk weights diminish and consequently required capital is reduced (Strategy 1 - Sell non-liquid assets, buy liquid assets). Institutions can increase the required amount of liquid assets, which impacts on the risk-based capital ratio and also on the banks' leverage ratio (Strategy 6 Leveraging). The LCR also incentivises banks to manage their funding in terms of maturity and counterparty. Neither lengthening the term of liabilities, smoothing the maturity structure of liabilities or focusing on different counterparties, however, affects capital ratios at all.

It is also important to highlight that sovereign bonds and central bank reserves within the liquid assets have most impact on LCR. Most institutions which significantly improved LCR did so by increasing sovereign bonds and drawable central bank reserves. Once and if central banks tighten their liquidity policy and increase interest rates, banks would have to-substitute central bank reserves or would otherwise incur higher opportunity costs.

To the best of our knowledge, at the time this article was written, there are no publications on the basis of which it is possible to determine the impact of EBA scenarios on Basel III liquidity measurement ratios by neither academicians nor practitioners. The main difficulty in carrying out this work, which also limits it, was the reconstruction and estimates of certain items that make up the regulatory ratios, and in particular the availability of the necessary data which is subject to implementation by the banks over the last few years.

As for future research, once legislation becomes fully operational, the integration of bank databases with new information will surely open up new horizons of the search, enriching the sensitivity analysis on management strategies on liquidity risk.

\section{References}

Banerjee, R. N., \& Hitoshi, M. (2014). The Impact of Liquidity Regulation on Banks. BIS Bank for international settlements, WP No 470. Retrieved from http://www.bis.org/publ/work470.pdf

BCBS. (2008). Principles for Sound Liquidity Risk Management and Supervision. Basel Committee on Banking Supervision Bank for International Settlements Press \& Communications CH-4002 Basel, Switzerland, pp. $1-44$.

BCBS. (2010). Basel III: A global regulatory framework for more resilient banks and banking systems (pp. 1-77). December. Retrieved from http://www.bis.org/publ/bcbs189_dec2010.pdf

BCBS. (2011). Basel III: International regulatory framework for banks. Retrieved from http://www.basel-iii-accord.com/

BCBS. (2013). Basel III: The Liquidity Coverage Ratio and liquidity risk monitoring tools. Basel Committee on Banking Supervision Bank for International Settlements (pp. 1-75). January.

BCBS. (2014a). Frequently Asked Questions on Basel III's January 2013 Liquidity Coverage Ratio framework. Bank for International Settlements (pp. 1-13).

BCBS. (2014b). Basel III: the Net Stable Funding ratio (pp. 1-17). Retrieved from http://www.bis.org/bcbs/publ/d295.htm

Dantzig, G. B. (1963). Linear Programming and Extensions. Princeton, N.J: Princeton University Press. https://doi.org/10.1515/9781400884179

European Banking Authority (EBA) (2014a). Second report on impact assessment for liquidity measures under Article 509(1) of the CRR. Retrieved from https://www.eba.europa.eu/documents/10180/950548/2014+LCR+IA+report.pdf

European Banking Authority (EBA) (2014b). II monitoring exercise - results based on data as of 31 December 2013 (pp. 1-37). Retrieved from http://www.eba.europa.eu/documents/10180/534414

European Banking Authority (EBA). (2015). EBA Report “On Net Stable Funding Requirements under Article 510 of the CRR” (pp. 1-247). Retrieved from https://www.eba.europa.eu/documents/10180/983359/EBA-Op-2015-22+NSFR+Report.pdf

European Banking Authority. (2013). On Defining Liquid Assets in the LCR under the draft CRR. Retrieved from https://www.eba.europa.eu/documents/10180/42030/DP-on-defining-liquid-assets-in-the-LCR.pdf/8d39f0bc 
$-248 \mathrm{e}-4185-8 \mathrm{cda}-7 \mathrm{f} 7 \mathrm{ff} 153 \mathrm{~b} 644$ ?version $=1.0$

European Parliament and of the Council. (2013). Regulation (EU) No 575/2013 of the European Parliament and of the Council of 26 June 2013 on prudential requirements for credit institutions and investment firms and $\begin{array}{llllll}\text { amending } & \text { Regulation } & \text { (EU) No } & \text { Notrieved } & \text { from }\end{array}$ http://eur-lex.europa.eu/legalcontent/EN/TXT/?uri=CELEX:32013R0575

European Parliament and of the Council. (2014). Commission Delegated Regulation (EU) 2015/61 of 10 October 2014 to supplement Regulation (EU) No 575/2013 of the European Parliament and the Council with regard to liquidity coverage requirement for Credit Institutions. (n. d.). http://eur-lex.europa.eu/legal-content/EN/TXT/?uri=CELEX\%3A32015R0061

European Parliament and of the Council. (n. d.). Commission "Delegated Regulation (EU) 2015/62 of 10 October 2014 amending Regulation (EU) No 575/2013 of the European Parliament and of the Council with regard to the leverage ratio".

European Parliament and of the Council. (n. d.). Commission "Delegated Regulation (EU) 2015/63 of 21 October 2014 supplementing Directive 2014/59/EU of the European Parliament and of the Council with regard to ex ante contributions to resolution financing arrangements". Retrieved from http://eur-lex.europa.eu/legal-content/EN/TXT/?uri=CELEX\%3A32015R0063

Gass, S. (1964). Linear Programming (2nd ed.). New York: McGraw-Hill.

Nash, S. G. (1990). A history of scientific computing. ACM, New York, NY.

Nash, S. G., \& Sofer, A. (1996). Linear and Nonlinear Programming. New York: McGraw-Hill.

Nazareth, J. L. (1987). Computer solution of linear programs. New York, NY: Oxford University Press, Inc.

Nelder, J. A., \& Mead, R. (1965). A Simplex Method for Function Minimization. Computer J., 7, 308-313. https://doi.org/10.1093/comjnl/7.4.308

Sande, G. (1984). Automated Cell Suppression to Preserve Confidentiality of Business Statistics. Statistical J. United Nations ECE, 2, 33-41.

The European Banking Federation. (2014). European Banking Sector Facts \& Figures 2013 (pp. 1-152). Retrieved from http://www.ebf-fbe.eu/publications/statistics/

\section{Appendix 1.}

\section{Construction of LCR Items and Calibration through Optimization Problems}

The key components of outflows and inflows were calibrated using EBA results in that they were based on detailed data from the main European banks. Given the homogeneity of the top banking groups, average values were used.

\section{MODEL CALIBRATION USING OPTIMIZATION TECHNIQUES}

For calibration it was decided to apply Simplex linear programming. The Simplex algorithm is used for linear programming, a technique used to solve models with linear objective function and linear constraints. The Simplex Algorithm developed by Dantzig (1963) is used to solve linear programming problems (See Dantzig, 1963; Gass, 1964; Nash, 1990; Nash \& Sofer, 1996; Nazareth, 1987; Sande, 1984)

Mathematically, the problem can be presented as follows:

$$
\begin{gathered}
\text { Optimize y }=f\left(x_{1}, x_{2}, \ldots, x_{n}\right) \\
\text { subject to } g_{j}\left(x_{1}, x_{2}, \ldots, x_{n}\right)\left\{\begin{array}{l}
\leq \\
= \\
\geq
\end{array}\right\} b_{j} \quad j=1,2, \ldots, m
\end{gathered}
$$

Where Equation E.1 is the objective function and Equation E.2. constitutes the set of constraints imposed on the solution. The $x_{i}$ variables, $x_{1}, x_{2}, \ldots, x_{n}$, represent the set of decision variables, and $\mathrm{y}=f\left(x_{1}, x_{2}, \ldots, x_{n}\right)$ is the objective function expressed in terms of these decision variables. Depending on the nature of the problem, the term 'optimize' means either maximize or minimize the value of the objective function. As indicated in Equation E.2, each constraint can take the form of an equality $(=)$ or an inequality $(<=$ or $>=)$ relationship. 


\section{Description of the model:}

The study document by Basel Committee on Banking Supervision (EBA 2014) is of significant interest for the present work because it contains LCR outflows and inflows (post-factor) as a percentage of balance sheet liabilities. The document is the publication of the EBA's Basel III monitoring exercise (EBA 2014) and summarizes the results at EU level. It assesses a total of 151 banks (participants), including 42 large internationally active banks ("Group 1 banks", defined as internationally active banks that have Tier 1 capital of more than $€ 3$ billion) and 109 Group 2 banks (i.e. representative of all other banks).

Table 1 shows the structure of the outflows and inflows.

Since Basel III compliance is still in a development phase that requires time and higher costs in the form of technology processes, therefore investment and process reorganization, the main difficulty in studying the new Basel III Liquidity Ratios today is lack of detailed bank data. Not all banks provide data relating to all parts of the Basel III framework.

Table 1. LCR outflows and inflows (post-weighting-factor) as a percentage of balance sheet liabilities

\begin{tabular}{l|c|c}
\hline & Group 1 & Group 2 \\
\hline Number of banks & 38 & 101 \\
\hline Unsecured retail and small business customers & 1.6 & 1.8 \\
\hline Unsecured non-financial corporates & 2.6 & 1.1 \\
\hline $\begin{array}{l}\text { Unsecured sovereign, central bank, public sector entities and other } \\
\text { counterparties }\end{array}$ & 0.6 & 0.4 \\
\hline Unsecured financial institutions and other legal entities & 4.3 & 2.7 \\
\hline Other unsecured wholesale funding incl. unsecured debt issuance & 1.2 & 0.8 \\
\hline Secured funding and collateral swaps & 1.7 & 0.4 \\
\hline Collateral, securitisations and own debt & 0.3 & 0.4 \\
\hline Credit and liquidity facilities & 1.4 & 0.6 \\
\hline $\begin{array}{l}\text { Other contractual and contingent cash outflows including derivative } \\
\text { payables }\end{array}$ & 2.8 & 1.7 \\
\hline Total outflows & 16.5 & $\mathbf{9 . 7}$ \\
\hline & & \\
\hline Secured lending & Group 1 & Group 2 \\
\hline $\begin{array}{l}\text { Retail and small business customers, non-financial corporates and other } \\
\text { entities }\end{array}$ & 1.4 & 0.4 \\
\hline Financial institutions & 1.5 & 0.9 \\
\hline Other cash inflows including derivative receivables & 1.4 & 1.5 \\
\hline Total inflows before applying the 75\% cap & 1.0 & 0.2 \\
\hline Total inflows after applying the 75\% cap & 5.4 & 3.0 \\
\hline
\end{tabular}

Source: Basel III monitoring exercise (September 2014).

\section{Objective:}

This step aimed at calibration of the liquidity balance sheet items in order to make them coherent to the EBA's Basel III monitoring exercise, through finding the optimal way of splitting the available items to achieve our objective, i.e to improve the Liquidity coverage ratio. For this purpose it is important to maximize the inflows and minimize the outflows.

Therefore, several models were built. The first model consists of the following components:

- Decision variables: The decisions are represented using symbols such as $\mathrm{X} 1, \mathrm{X} 2, \mathrm{X} 3, \ldots . \mathrm{Xn}$. These variables represent amounts split from every available bank balance sheet component into separate sub-item with certain specific features.

\section{VARIABLES FOR OUTFLOWS MODELING}

X1 = Amount of TERM DEPOSITS Retail deposits Stable deposits (deposit insurance scheme meets additional criteria)
$\mathrm{X} 2$ = Amount of TERM DEPOSITS
Retail deposits Stable deposits
$\mathrm{X} 3$ = Amount of TERM DEPOSITS
Retail deposits Less stable retail deposits
$\mathrm{X} 4$ = Amount of TERM DEPOSITS
Small business customers Stable deposits
X5 = Amount of TERM DEPOSITS
Small business customers Less stable
$\mathrm{X} 6$ = Amount of TERM DEPOSITS
Non-financial Corporate Non-financial Corporate 
X7 = Amount of TERM DEPOSITS Sovereigns, PSEs (Public Sector Entities), multilateral development banks Sovereigns, PSEs (Public Sector Entities),

$\mathrm{X} 8=$ Amount of DEMAND DEPOSITS Retail deposits Stable deposits (deposit insurance scheme meets additional criteria)

X9 = Amount of DEMAND DEPOSITS Retail deposits Stable deposits

$\mathrm{X} 10=$ Amount of DEMAND DEPOSITS Retail deposits Less stable retail deposits

$\mathrm{X} 11=$ Amount of DEMAND DEPOSITS Small business customers Stable deposits

$\mathrm{X} 12=$ Amount of DEMAND DEPOSITS Small business customers Less stable deposits

X13 = Amount of DEMAND DEPOSITS Non-financial Corporate Operational deposits generated by clearing, custody and cash management activities (insured: withdrawable part)

X14 = Amount of DEMAND DEPOSITS Non-financial Corporate Fully covered by deposit insurance scheme, Non operational

X15 = Amount of DEMAND DEPOSITS Non-financial Corporate Operational deposits generated by clearing, custody and cash management activities

X16 = Amount of DEMAND DEPOSITS Non-financial Corporate Unsecured funding, not specifically held for operational purposes

X17= Amount of DEMAND DEPOSITS Sovereigns, PSEs (Public Sector Entities), central banks, multilateral development banks Operational deposits generated by clearing, custody and cash management activities (insured: withdrawable part)

X18 = Amount of DEMAND DEPOSITS Sovereigns, PSEs (Public Sector Entities), central banks, multilateral development banks Fully covered by deposit insurance scheme, Non operational

X19 = Amount of DEMAND DEPOSITS Sovereigns, PSEs (Public Sector Entities), central banks, multilateral development banks Unsecured funding, not specifically held for operational purposes

$\mathrm{X} 20=$ Amount of DEMAND DEPOSITS Sovereigns, PSEs (Public Sector Entities), central banks, multilateral development banks Operational deposits generated by clearing, custody and cash management activities

X21= LONG TERM FUNDING Legal entity customers (banks, securities firms, insurance companies, etc)

X22 = Amount of OTHER MARKET COUNTERPART CURRENT ACCOUNTS Legal entity customers (banks, securities firms, insurance companies, etc)

X23 = Amount of OTHER MARKET COUNTERPART CURRENT ACCOUNTS Legal entity customers (banks, securities firms, insurance companies, etc)

X24 = Amount of LIABILITIES IN TERMS OF MONETARY POLICY (COLLATERALIZED)

$\mathrm{X} 25$ = Amount of REPO (Repurchase agreements) REPO (Repurchase agreements) REPO (Repurchase agreements)

X26 $=$ Amount of DERIVATIVES LIABILITIES DERIVATIVES LIABILITIES DERIVATIVES

LIABILITIES

X27 = Amount of PROVISIONS FOR IMPAIRMENT OF ASSETSPROVISIONS FOR IMPAIRMENT OF ASSETS PROVISIONS FOR IMPAIRMENT OF ASSETS

$\mathrm{X} 28$ = Amount of MARGIN CALLS LIABILITIES (CASH COLLATERAL FOR DERIVATIVES)

\section{VARIABLES FOR INFLOWS MODELING}

$\mathrm{X} 1$ = Amount of PERFORMING LOANS

$\mathrm{X} 2$ = Amount of PERFORMING LOANS

$\mathrm{X} 3$ = Amount of PERFORMING LOANS multilateral development banks

X4 = Amount of OTHER PERFORMING RECEIVABLES

X5 = Amount of OTHER PERFORMING RECEIVABLES

$\mathrm{X} 6=$ Amount of OTHER PERFORMING RECEIVABLES
Retail customers

Non-financial Corporate

Sovereigns, PSEs (Public Sector Entities), central banks,
Retail customers

Small business customers

Non-financial Corporate 
X7 = Amount of OTHER PERFORMING RECEIVABLES Sovereigns, PSEs (Public Sector Entities), central banks, multilateral development banks

$\mathrm{X} 8=$ Amount of PERFORMING LOAN TO MARKET COUNTERPARTY Credit institutions

X9 = Amount of DERIVATIVES ASSETS

\section{- Objective function:}

The Objective for the first model is to maximize the inflows. Maximize $\mathrm{f}(\mathrm{X} 1, \mathrm{X} 2, \mathrm{X} 3, \mathrm{X} 4, \mathrm{X} 5$..) $)$ expression in decision variables. Meanwhile the Objective for the second model is to minimize the outflows.

Inflows: Maximize $\mathrm{f}(\mathrm{X} 1, \mathrm{X} 2, \mathrm{X} 3, \mathrm{X} 4, \mathrm{X} 5)=\mathrm{a} 1 \% \mathrm{X} 1+\mathrm{a} 2 \% \mathrm{X} 2+\mathrm{a} 3 \% \mathrm{X} 3+\mathrm{a} 4 \% \mathrm{X} 4+\mathrm{a} 5 \% \mathrm{X} 5 \ldots .$. etc.

where a1...aN are percentages that incorporate two components:

1) Split percentages of bank balance sheet items into a subitem with certain specific features in correspondence with regulatory requirements

2) Stress scenario \% risk weight. The Committee has presented this scenario which combines firm-specific shock with a market shock that would result in the Basel III shock scenario. Cash outflows are subject to prescribed 'run - off' rates while cash inflows are subject to prescribed 'inflow factors'.

- Constraints: inequalities or equations in decision variables.

The first group of constraints is based on Table 1, which shows the structure of the main items of outflows and inflows from the EBA's Basel III monitoring exercise (EBA 2014).

\section{Inflows:}

$0.5 \times 2+0.5 \times 3+0.5 \times 4+0.5 \times 5+0.5 \times 6+0.5 \times 7+0.5 \times 8+0.5 \times 9=7.776 .445$ (2. INFLOWS - RETAIL\&SME, NON-FINANCIAL CORPORATES AND OTHERS)

$0.5 \mathrm{X} 10=7.258 .016$ ( 3 . INFLOWS - FINANCIAL INSTITUTIONS)

$0.5 \times 10=5.184 .297$ ( 4 . INFLOW - OTHER CASH INFLOWS INCLUDING DERIVATIVE RECEIVABLES)

\section{Outflows:}

$0.1 \mathrm{X} 3+0.1 \mathrm{X} 10=8.294 .875$ (1.OUTFLOW - UNSECURED RETAIL \&SME)

$0.4 \mathrm{X} 6+0.25 \mathrm{X} 15+0.3 \mathrm{X} 16=13.479 .172(2$. OUTFLOW - UNSECURED NON-FINACIAL CORPORATES $)$

$0.5 \mathrm{X} 7+0.4 \mathrm{X} 19+0.25 \mathrm{X} 20=3.110 .578$ ( 3 . OUTFLOW - UNSECURED SOVEREIGNS, CENTRAL BANK, PUBLIC SECTOR, OTHER)

$1 \mathrm{X} 21+1 \mathrm{X} 22+1 \mathrm{X} 23=22.292 .477,01$ (4. OUTFLOW - UNSECURED FINANCIAL INSTITUTION AND OTHER LEGAL ENTITIES)

$1 \mathrm{X} 25=8.813 .304,86$ (6. OUTFLOW - SECURED FUNDING AND COLLATERAL SWAP

$1 \mathrm{X} 24+1 \mathrm{X} 31=1.555 .289,09$ (7. OUTFLOW - COLLATERAL, SECURITISATIONS AND OWN DEBT)

$0.5 \mathrm{X} 29+0.4 \mathrm{X} 30=7.258 .015,77$ (8. OUTFLOW CREDIT AND LIQUIDITY FACILITIES)

$0.5 X 29+0.4 X 30=14.516 .031,54$ (9. OUTFLOW - OTHER CONTRACTUAL AND CONTINGENT CASH OUTFLOWS INCLUDING DERIVATIVE PAYABLES)

The second group of constraints is based on the Financial Sector Analysis:

Outflows:

Term Retail Deposits : X1+ X2+ X3 =76.3\%* Term Deposit

Term Business Deposits : X4+ X5+ X6 =22.7\%* Term Deposit

Nonnegativity constraints (all the variables should be nonnegative):

$\mathrm{X} 1, \mathrm{X} 2, \mathrm{X} 3, \mathrm{X} 4, \mathrm{X} 5>=0$.

In order to model implementation mathematically and find the optimal solution to optimization problems the Solver spreadsheet modeling was used.

Key depositors are: governments (CG), monetary financial institutons (MFI), businesses (NFC), households (HH), insurance corporations and pension funds (ICPF) and other financial institutons (OFI). The table below shows the breakdown of main deposit types at these institutions. 
Table 2. Breakdown by type of Euro area deposits

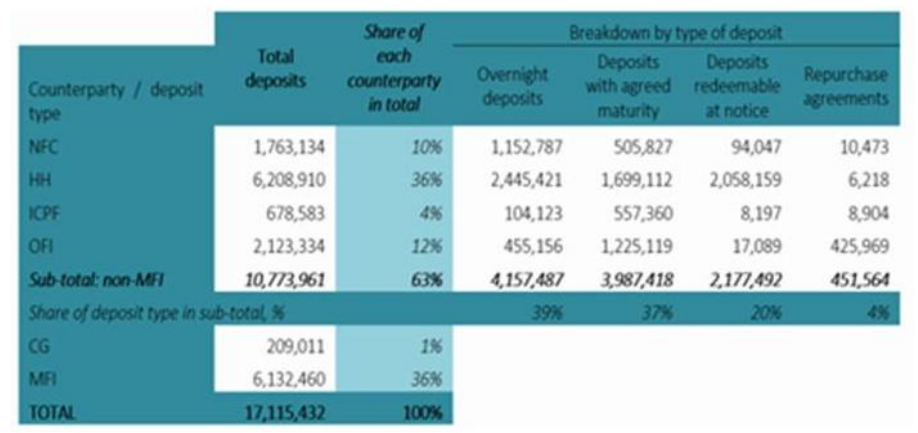

Source: ECB, European Banking Federation 2014.

As for Inflows, the following breakdown has been used to split performing loans

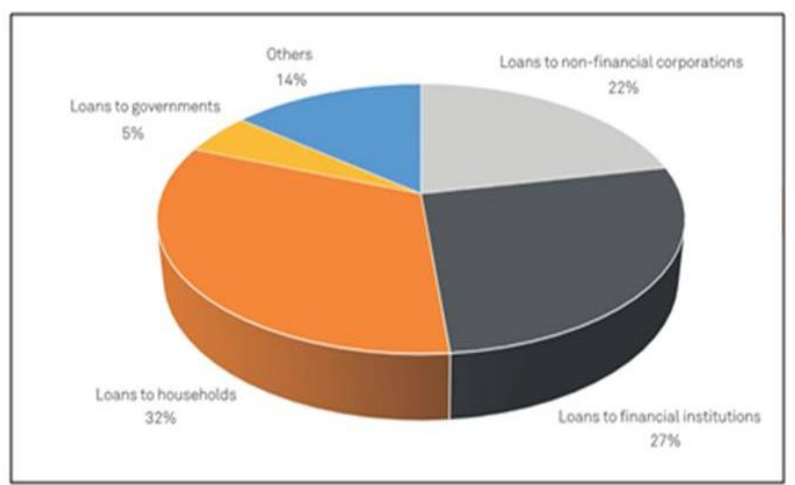

Figure 7. EU bank loan volumes by sector

Source: European Banking Federation 2014.

Further assumptions of the model:

$6 \%$ of Qualifying marketable securities from sovereigns is mobilized in other operations, its market value reaches $95 \%$ accounting value.

\section{Appendix 2.}

Table 3. Summary of liability categories and associated ASF factors

\begin{tabular}{|c|l|}
\hline ASF factor & Components of ASF category \\
\hline $100 \%$ & $\begin{array}{l}\text { - Total regulatory capital (excluding Tier } 2 \text { instruments with residual maturity } \\
\text { of less than one year) } \\
\text { - Other capital instruments and liabilities with effective residual maturity of } \\
\text { one year more }\end{array}$ \\
\hline $95 \%$ & $\begin{array}{l}\text { - Stable non-maturity (demand) deposits and term deposits with residual } \\
\text { maturity of less than one year provided by retail and small business customers }\end{array}$ \\
\hline $90 \%$ & $\begin{array}{l}\text { - Less stable non-maturity deposits and term deposits with residual maturity of } \\
\text { less than one year provided by retail and small business customers }\end{array}$ \\
\hline $50 \%$ & $\begin{array}{l}\text { - Funding with residual maturity of less than one year provided by non- } \\
\text { financial corporate customers } \\
\text { - Operational deposits } \\
\text { Funding with residual maturity of less than one year from sovereigns, PSEs, } \\
\text { and multilateral and national development banks } \\
\text { Other funding with residual maturity between six months and less than one } \\
\text { year not included in the above categories, including funding provided by } \\
\text { central banks and financial institutions }\end{array}$ \\
\hline $0 \%$ & $\begin{array}{l}\text { - All other liabilities and equity not included in the above categories, including } \\
\text { liabilities without a stated maturity (with a specific treatment for deferred tax } \\
\text { liabilities and minority interests) } \\
\text { - NSFR derivative liabilities net of NSFR derivative assets if NSFR derivative } \\
\text { liabilities are greater than NSFR derivative assets } \\
\text { "Trade date" payables arising from purchases of financial instruments, } \\
\text { foreign currencies and commodities }\end{array}$ \\
\hline
\end{tabular}

Source: BCBS 2014b 
Table 4. Summary of asset categories and associated RSF factors

\begin{tabular}{|c|c|}
\hline $\begin{array}{c}\text { RSF } \\
\text { factor }\end{array}$ & Components of RSF category \\
\hline $0 \%$ & $\begin{array}{l}\text { - Coins and banknotes } \\
\text { - All central bank reserves } \\
\text { - All claims on central banks with residual maturities of less than six months } \\
\text { - "Trade date" receivables arising from sales of financial instruments, foreign } \\
\text { currencies and commodities. }\end{array}$ \\
\hline $5 \%$ & $\begin{array}{l}\text { - Unencumbered Level } 1 \text { assets, excluding coins, banknotes and central bank } \\
\text { reserves }\end{array}$ \\
\hline $10 \%$ & $\begin{array}{l}\text { - Unencumbered loans to financial institutions with residual maturities of less } \\
\text { than six months, where the loan is secured against Level } 1 \text { assets as defined in } \\
\text { LCR paragraph } 50 \text {, and where the bank has the ability to freely rehypothecate the } \\
\text { received collateral for the life of the loan }\end{array}$ \\
\hline $15 \%$ & $\begin{array}{l}\text { - All other unencumbered loans to financial institutions with residual maturities } \\
\text { of less than six months not included in the above categories } \\
\text { - Unencumbered Level 2A assets }\end{array}$ \\
\hline $50 \%$ & $\begin{array}{l}\text { - Unencumbered Level 2B assets } \\
\text { - HQLA encumbered for a period of six months or more and less than one year } \\
\text { - Loans to financial institutions and central banks with residual maturities } \\
\text { between six months and less than one year } \\
\text { - Deposits held at other financial institutions for operational purposes } \\
\text { - All other assets not included in the above categories with residual maturity of } \\
\text { less than one year, including loans to non-financial corporate clients, loans to } \\
\text { retail and small business customers, and loans to sovereigns and PSEs }\end{array}$ \\
\hline $65 \%$ & $\begin{array}{l}\text { - Unencumbered residential mortgages with a residual maturity of one year or } \\
\text { more and with a risk weight of less than or equal to } 35 \% \text { under the Standardised } \\
\text { Approach } \\
\text { - Other unencumbered loans not included in the above categories, excluding } \\
\text { loans to financial institutions, with a residual maturity of one year or more and } \\
\text { with a risk weight of less than or equal to } 35 \% \text { under the standardised approach }\end{array}$ \\
\hline $85 \%$ & $\begin{array}{l}\text { - Cash, securities or other assets posted as initial margin for derivative contracts } \\
\text { and cash or other assets provided to contribute to the default fund of a CCP } \\
\text { - Other unencumbered performing loans with risk weights greater than } 35 \% \\
\text { under the standardised approach and residual maturities of one year or more, } \\
\text { excluding loans to financial institutions } \\
\text { - Unencumbered securities that are not in default and do not qualify as HQLA } \\
\text { with a remaining maturity of one year or more and exchange-traded equities } \\
\text { - Physicaltradedcommodities, includinggold }\end{array}$ \\
\hline $100 \%$ & $\begin{array}{l}\text { - All assets that are encumbered for a period of one year or more } \\
\text { - NSFR derivative assets net of NSFR derivative liabilities if NSFR derivative } \\
\text { assets are greater than NSFR derivative liabilities } \\
\text { - } 20 \% \text { of derivative liabilities as calculated according to paragraph } 19 \\
\text { - All other assets not included in the above categories, including non-performing } \\
\text { loans, loans to financial institutions with a residual maturity of one year or more, } \\
\text { non-exchange-traded equities, fixed assets, items deducted from regulatory } \\
\text { capital, retained interest, insurance assets, subsidiary interests and defaulted } \\
\text { securities }\end{array}$ \\
\hline
\end{tabular}

Source: BCBS $2014 \mathrm{~b}$

Table 5. Summary of off-balance sheet categories and associated RSF factors

\begin{tabular}{|c|l|}
\hline $\begin{array}{c}\text { RSF factor } \\
\text { currently } \\
\text { undrawn } \\
\text { portion }\end{array}$ & $\begin{array}{l}\text { RSF category } \\
\text { Irrevocable and conditionally revocable credit and liquidity facilities to any } \\
\text { client }\end{array}$ \\
\hline $\begin{array}{l}\text { Other contingent funding obligations, including products and instruments } \\
\text { such as: } \\
\text { - Unconditionally revocable credit and liquidity facilities } \\
\text { - Trade finance-related obligations (including guarantees and letters of } \\
\text { credit) }\end{array}$ \\
$\begin{array}{c}\text { National } \\
\text { supervisors } \\
\text { can specify the factors } \\
\text { based on their } \\
\text { national } \\
\text { circumstances }\end{array}$ & $\begin{array}{l}\text { - Non-contractual obligations such as: } \\
\text { related conduits, securities investment vehicles and other such financing } \\
\text { facilities }\end{array}$ \\
& $\begin{array}{l}\text { - structured products where customers anticipate ready marketability, such } \\
\text { as adjustable rate notes and variable rate demand notes (VRDNs) }\end{array}$ \\
& $\begin{array}{l}\text { - managed funds that are marketed with the objective of maintaining a stable } \\
\text { value }\end{array}$ \\
\hline
\end{tabular}

\section{Copyrights}

Copyright for this article is retained by the author(s), with first publication rights granted to the journal.

This is an open-access article distributed under the terms and conditions of the Creative Commons Attribution license (http://creativecommons.org/licenses/by/4.0/). 